J. Gen. Appl. Microbiol.

Vol. 8, No. 1, 1962

\title{
TAXONOMIC STUDY ON THE GENUS PICHIA HANSEN (2)
}

\author{
KENKICHI KODAMA, TADASHI KYONO and SHOJIRO KODAMA \\ Laboratory of Kodama Brewing Co. Ltd. \\ Received for publication, November 6, 1961
}

\section{INTRODUCTION}

This paper deals with a yeast isolated from exudation of a tree stump (Carpinus spec.) in Japan. Taxonomic study on this isolate revealed that it represents a new species belonging to the Genus Pichia Hansen.

\section{METHODS AND EXPERIMENTAL RESULTS}

Details of the isolation technique and taxonomic procedure have been described in the previous report (1).

\section{DESCRIPTION}

Pichia saitoi nov. spec.

Growth in malt extract: After 3 days at $25^{\circ} \mathrm{C}$ cells are short oval to oval, not cylindrical, single or in pairs (3-6.5) $\times(45-8.5) \mu$ (Fig. 1). At first strong gaseous fermentation occurs; after 2 days at $25^{\circ} \mathrm{C}$, a sediment and a thin, wet, almost smooth, creeping pellicle are formed.

Growth on malt agar: After 1 month at $17^{\circ} \mathrm{C}$, the streak culture is greyish white to dark yellowish brown, somewhat shiny, flat, almost smooth.

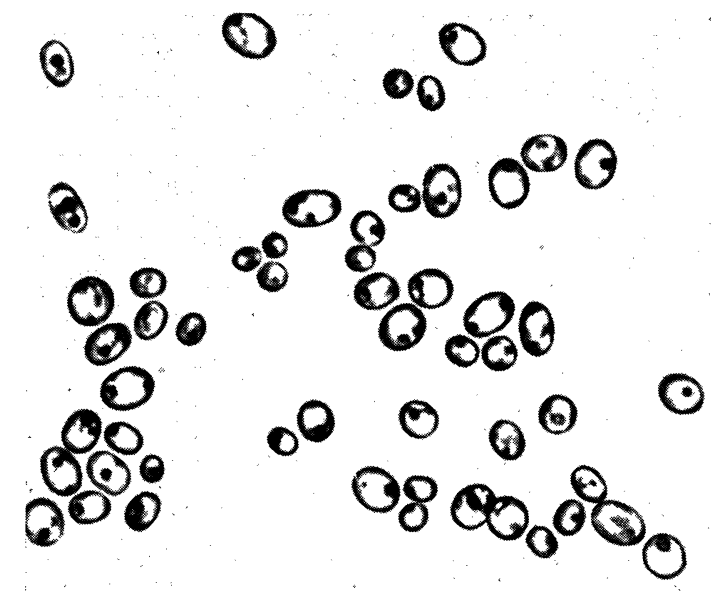

Fig. 1. Cells in malt extract $(\times 800)$ 


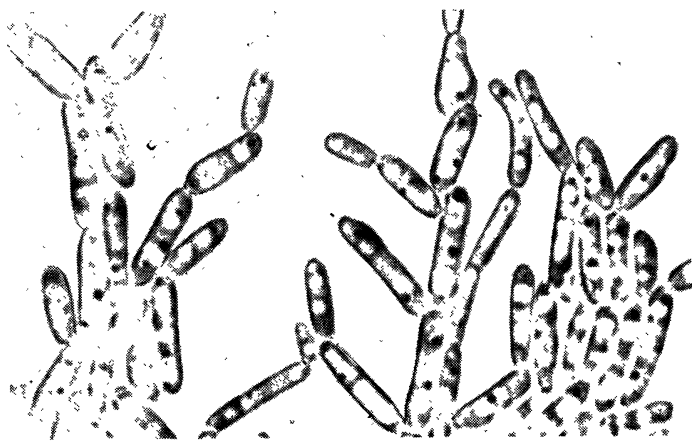

Fig. 2 Slide cultures on Potato agar. $(\times 800)$

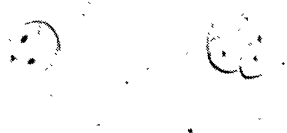

Fig. 3. Drawings of ascospores

The margin is almost smooth.

Slide cultures: Rather primitive pseudomycelium is formed; there is no diference between pseudomycelial cells and blastospores (Fig. 2).

Sporulation: Asci are formed without preceding conjugation on $\mathrm{V}-8$ and glucose-potato agar which turns out to be chocolate brown due to sporulation. The spores apparently seem to be roundish to oblate oval with an oildrop in the middle. However, on detailed observations, some of the spores were found to be lemon or saturn shaped with slight ledges.

Further observation under the electron microscope revealed that most spores were saturn-shaped, each with a distinct ledge in the middle or near the one side, 14 spores per ascus. (2) The asci rupture readily after maturation, releasing ascospores (Fig. 3).

Fermentation: glucose + , glactose-, saccharose-, maltose-, lactose-, raffinose-; Sugar assimilation: glucose + , galactose-, saccharose-, maltose-, lactose-. Assimilation of potassium nitrate: negative.

Ethanol as sole source of carbon: growth.

Splitting of arbutin: negative.

Vitamin requirement: added vitamins are required.

Maximum temperature for growth: $35-36^{\circ} \mathrm{C}$.

Source of isolation: single culture of $060-\mathrm{L}$. K. B. was isolated from exudation of a tree stump (Carpinus spec.) in Miye Prefecture (Japan).

\section{DISCUSSION}

As above mentioned, the isolate of film forming yeast does not assimilate potassium nitrate, by which it can be clearly classified in the Genus Pichia. It resembles Pichia terricola VAN Der WALt (3) and Pichia fermentans LODDER (4) not only in its assimilation and fermentation of glucose only, but also in the following points.

i) Morphologically, it resembles the former in the feature of streak culture which turns out to be chocolate brown due to sporulation. 
ii) Physiologically, its strong activity of fermenting glucose is comparable to that of the latter.

A remarkable difference lies, however, in the shape of ascospores. Most of the ascospores of the isolate are lemon or saturn-shaped, in contrast to those of the other two species which have already been discussed in the previous report. (1). This difference in the shape of ascospores was not only observed under the optical microscope, but also ascertained by electron microscopic pictures. Because of the unique shapes of ascospores which have never been described for any species of the Genus Pichia Hansen hitherto reported, the isolate under discussion may be regarded as a new species, for which the authors wish to propose the name Pichia saitoi nov. spec. in honour of the late Dr. Kendo SAITo, former Emeritus Professor, University of Osaka, for his outstanding contributions to microbiology in the Orient.

A culture of Pichia saitoi has been deposited in the Yeast Collection of the Centraalbureau voor Schimmelcultures in Delft.

\section{LATIN DIAGNOSIS}

Pichia saitoi nov. spec.

In musto maltato cellulae ovoideae $(3-6.5) \times(4.5-8.5)$ u. singulae aut binae. Post dies 2-3, pellicula, tenuis laevis prostrata sedimentum formatur. In agaro maltato, cultura (post unum mensem $17^{\circ} \mathrm{C}$ ) griseo-alba aut lurida applanata, nitidula fere laevis.

Pseudomycelium formatur.

Asci formatur ex transformatione cellularum vegetativarum diploidearum.

Ascosporae citriformes aut saturniformes 1-4 in asco.

Cultura in agaro (V-8, glucoso-potato etc.) pallidibadie colorata ob sporulationem.

Fermentatio glucosi solius. In medio minerali cum glucoso solo crescitur.

Nitras Kalicus non assimilatur.

In medio minerali cum alcohole aethylico crescitur, pellicula formatur.

Arbutinum non finditur.

Necessariae ad crescentiam sunt vitaminae externae.

Isolata ex fluxu ex trunco caesco Carpini.

\section{SUMMARY}

A new species of yeast belonging to the Genus Pichia Hansen was isolated from exudation of a tree stump, (Carpinus spec.) in Japan. The name Pichia saitoi was proposed for this microorganism. A characteristic feature of this species is in its unique shape of ascospores.

\section{ACKNOWLEDGEMENT}

The authors wish to express their hearty thanks to Mrs. N. J. W. KrEger-van RIJ who gave kind assistance to their study. Thanks are also 
due to Mr. K. Yамамото for his kindness in supplying the sample from which the organism was isolated.

\section{ADDENDUM}

According to Dr. H. J. PhafF's communication to one of the authors, the Genus Pichia should not be followed by the name Phaff, but still be called Pichia Hansen. Therefore, from this paper on, we adopt the name of Pichia HANSEN.

\section{REFERENCES}

(1) K. Kodama, T. Kyono and S. Kodama: J. Gen. Appl. Microbiol. 7, 227 (1961).

(2) N. KaWaKami, T. Nehira and K. Kodama: The public lecture of University of Osaka (1961).

(3) J. P. VAN DER WALT: Antonie van Leeuwenhoek 23, 23 (1957).

(4) Lodder, J. and N. J. W. KREger-van RiJ: The Yeasts. A taxonomic study (1952). 